\title{
Leaders' Normative Isomorphic Pressure Response and Survivability of Telecommunication Firms in Nigeria
}

\author{
Chinonye Chris Wobodo, Soye Peniel Asawo \\ Department of Management, Faculty of Management Sciences, Rivers State University, Port Harcourt, Nigeria \\ Email address: \\ chinonyewobodo@gmail.com (C. C. Wobodo), soye.asawo@ust.edu.ng (S. P. Asawo)

\section{To cite this article:} \\ Chinonye Chris Wobodo, Soye Peniel Asawo. Leaders' Normative Isomorphic Pressure Response and Survivability of Telecommunication \\ Firms in Nigeria. Journal of Business and Economic Development. Vol. 6, No. 3, 2021, pp. 125-132. doi: 10.11648/j.jbed.20210603.11
}

Received: April 23, 2021; Accepted: June 7, 2021; Published: June 25, 2021

\begin{abstract}
This study empirically examined the interlace between leaders' normative isomorphic pressure response and survivability of telecommunication firms in Nigeria. The theoretical foundation of the study was based on the organizational embeddedness theory. The study adopted the cross-sectional survey design with a population of 198 executive and managerial staff of the four telecommunication firms in Nigeria. Given the manageable population size, the census sample size determination technique was adopted. The study data were gathered using structured questionnaire which was validated by expert review. In order to confirm the reliability of the study instrument, the Cronbach alpha test was conducted with all variables having coefficients above the 0.7 threshold. The Pearson Product Moment Correlation coefficient was used to assess the interlace between the study variable with the aid of Statistical Package for Social Sciences version 21.0. The study discovered that leaders' normative isomorphic pressure response positively and significantly interlaces with survivability measured by innovation and growth. Consequently, the study concludes that through the positive response of organizational leaders, telecommunication firms in Nigeria as affirmed by various professional bodies within the confines of their operational requirements, become progressively aware of global best practices in the world of business which in the long run validate their social legitimacy standing, and enhancing their chances of survivability goal attainment. Thus, the study recommends that the leaders of telecommunication firms in Nigeria should always encourage their staff members to regularly apply their respective professional ethical codes in the discharge of their daily work roles in the organization.
\end{abstract}

Keywords: Normative Pressure, Survivability, Innovation, Growth, Telecoms Firms

\section{Introduction}

The telecommunication sector in Nigeria has been acknowledged to have experienced rapid growth in the last two decades, facilitated by the deregulation of the sectors [40]. This rapid growth coincides with the massive inflow of both local and foreign private investments into the sector. Similarly, it has been argued [18] that telecommunication sector in the Sub-Saharan African region is growing at a faster pace than other sectors due to significant investment from the private sector. With this observable increase in private sector participation, it will be expected that survivability of telecommunication firms will be guaranteed to a large extent. This is because through significant shareholders' investments channels, firms receive huge financial resources to pursue their outlined goals and objectives. These goals as identified by scholars include customer or value creation [16], profitability, growth and expansion, good corporate citizenship behavior, goodwill, survival and market share growth [26]. Underlying these myriad of goals is the desire for survivability. This is because it is only a living business that can maximize profit and expand market share.

But, according to Ugwuzor (2017), as essential as survivability is in the pursuit of overall business performance, it is often difficult to realize it without leadership interest to drive and sustain the organization. Sadly, in Nigeria, a number of organizations within the telecommunication sector have failed to survive the transition phase of the industry, which may be attributed to leadership failure. For instance, V-Mobile Nigeria did not last beyond two years in the Nigerian telecom sector as the company was bought over by Celtel to the tune of $\$ 1.005$ billion US dollars in 2006. Celtel Nigeria suffered a similar fate in 2008 due to its inability to 
synchronize various isomorphic pressures through quality management, and was thus sold to Zain to the tune of $\$ 3$ billion US dollars. In 2017, Zain Nigeria was out rightly handed over to Bharti Airtel Nigeria following the sale of Zain Africa to Bharti Airtel India. According to Broad Communication, a major shareholder of Zain, the company could not survive in the industry because of unethical management practices such as fraud, mismanagement, and capital flight by Zain Group, Kuwait amounting to the tune of \#16.6 billion as well as the firm's inability to pay shareholders' dividends.

In organizations' quest for survivability, different predictor variables have been adopted by scholars and managers in practice. However, there is a dearth of empirical investigations on the efficacy of leaders' objective response to normative isomorphic pressure in the Nigerian telecommunication sector as most of such studies have been conducted either in other climes or in other sectors of the Nigerian economy. For instance, research focus has been directed at the impact of institutional pressures on the adoption of green supply chain management in Brazil [50]. Some researchers [19] examined the relationship between entrepreneurial orientation and survivability of banks in Nigeria while others [10] investigated the relationship between innovation and their determinants of company survival within the manufacturing industry. These studies have shown that achieving the survivability goal amid other goals requires leader's objective response to various normative isomorphic pressures in the organization's operations as a primary source of social legitimacy. As a social system, responding to these pressures as they emerge is considered as a precondition for survivability goal attainment, especially because no organization is internally self-sufficient. Thus, institutional isomorphism has emerged as an important theoretical element in the new institutional theory (Scott, 2014) with normative isomorphism as a key empirical referent. Consequently, this study empirically examined the interlace between leaders' normative isomorphic pressure response and survivability of telecommunication firms in Nigeria.

\section{Conceptual Framework}

In alignment with the purpose of the study, a conceptual framework was developed to graphically enunciate the interlace between normative pressure and survivability as depicted in figure 1:

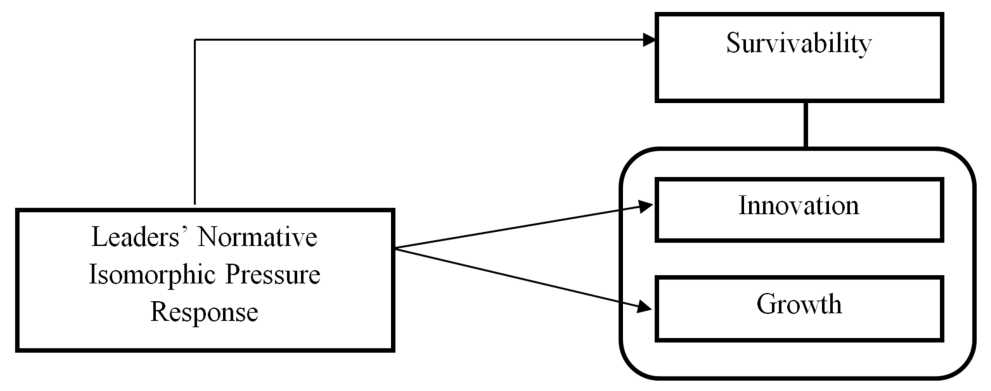

Source: Desk Research, 2021.

Figure 1. Conceptual Framework of Normative Pressure of Institutional Isomorphism and Survivability.

\section{Purpose and Objectives of the Study}

The purpose of this study was to examine the interlace between leaders' normative isomorphic pressure response and survivability of telecommunication firms in Nigeria. Accordingly, the objectives of the study are as follows:

i) To examine the interlace between leaders' normative isomorphic pressure response and innovation of telecommunication firms in Nigeria.

ii) To examine the interlace between leaders' normative isomorphic pressure response and growth of telecommunication firms in Nigeria.

\section{Research Questions}

Drawing from the study objectives, the following research questions were derived:

i) How does leaders' normative isomorphic pressure response interlace with innovation of telecommunication firms in Nigeria? ii) How does leaders' normative isomorphic pressure response interlace with growth of telecommunication firms in Nigeria?

\section{Literature Review}

\subsection{Theoretical Foundation}

The theoretical foundation of this study is built on the organizational embeddedness theory. Organizational embeddedness theory was advanced to showcase the power of the external environment in the determination of business survivability [24]. Since then, the idea of organizational embeddedness of economic action has been recurrently used to explain economic behavior in different contexts [23, 25]. According to a modern research view on the concept [24], embeddedness explains that all economic actions are entrenched in social relationship. Similarly, it has been shown that embeddedness is associated with the process through which social connection influences economic actions of people in manners that some mainstream economic 
arrangements are overlooked when they assume that social linkages affect economic behavior marginally [49]. This suggests that organizational action is premised on affiliation with other organizations. In other words, it means that for any organization operating within a population of organizations to survive, such organization must as a matter of necessity maintain strategic ties with other organizations.

\subsection{Concept of Normative Isomorphic Pressure}

The phenomenon of normative pressures on organizations and their leaders in a specific industry occur as a result of similar orientations, trainings and development processes organizations' members went through in their unique area of disciplines even though they studied in different locations across national frontiers. Normative pressure has been described as the collective struggle of members of an occupation to define the conditions and patterns in which their work can be executed and to institute a cognitive base for their occupational autonomy [8]. It has also been referred to as pressures that capture the means in which organizations are expected to conform to standards of professionalism and to adopt systems and techniques considered to be legitimate by relevant professional groupings [4]. Similarly, it has been alluded [41] that normative pressure is associated with the adoption of structures and patterns considered superior in line with professionalization standards. In their recent some scholars [47] conceptualization iterate that normative pressures are forces that emanate from the values of professionalism and the emergence of legitimate professional practices that result to isomorphism.

Tracing the source of normative isomorphic pressure, some scholars $[15,20]$ posit that normative pressure emerges through formal education and advice from professional organizations. It has therefore been posited [35] that normative pressure is a product of professionalization, involving two pressures. First, it is believed that members of professions acquire the same trainings which socialize them into similar approach in their task performance. Second, is that members of professions interact through professional and trade associations, which further circulate uniforms ideas among them. Professionalism is thus associated with members of an organization with their desire to maintain autonomy over work procedures [11]. Normative isomorphic pressure is in fact, a powerful vehicle through which organizations are conveyed toward convergence practices. This is as professionals engaged by their respective organizations strive to perform their task in accordance with the ethical codes of their professions in order to avoid sanction and possible withdrawal of their certification. This opinion is in line with the view that the professional organization is a specific example of a normative isomorphic pressure that is especially relevant to public organizations [21]. Organizational leaders are more likely to engage in professional organizations and being the key drivers of organizations and their culture formation, they are more prone to feeling and responding to these normative isomorphic pressures more than other organizational members. This is also in line with the observation that professional personnel go from one organization to another, bringing in their wealth of experience and their assumptions of how things are done, and not done [28]; which in effect imposes a great deal of homogenization within the field.

\subsection{Survivability}

Survivability refers to the capability of an organization to continuously meet with the demands of the market, its workforce, shareholders, investors, host communities, the government and other relevant stakeholders [19]. Drawing from this definition, it shows that for an organization to remain operationally alive, it must continuously ensure that all of its stakeholders' needs or interests are protected continuously. In the same manner, survivability has been viewed as the process of running a business organization as a going concern which is often referred to as managing to stay in business [2]. By implication, this means that when individuals set up a business, one of their primary objectives is to ensure its perpetuity; and they achieve this through quality leadership and succession planning. Here, entrepreneurs see corporate survival as the process of an organization existing beyond its founders. In support of this, it has been argued that firms always expect that they will remain viable and continue to exist and operate in the foreseeable future [48]. Consequently, survivability has been construed as referring to successful organizations, which are capable of achieving their goals and maintaining same over a long period of time [37]. Furthermore, it has been noted that survivability involves living over possible setbacks and organizational deaths accordingly [42].

Drawing from the forgoing definitions, survivability can be referred to as a state of continuous business existence even in the face of unforeseen environmental threats capable of breaking the organization. Thus, survivability is not something that can be given to an organization like a loan obtained from a bank; rather, it can only be earned by an organization through its hard work and resilience capacity in the face of the storm. It has therefore been argued that survival is an essential objective of every business [19]. Similarly, some scholars [26] added that the survival objective is key among business objectives in that it is only a living organization that can display ambitiousness or be motivated to pursue other long term business goals such as customer creation, profit maximization, growth and expansion, goodwill, etc. Key measures of survivability include innovation and growth.

\subsubsection{Innovation}

In modern business management, continuous improvement of processes and practices are considered strategic to continuous survivability. And studies have shown that one way organizations achieve this is through continuous innovation practice. The term innovation as conceptualized by Schumpeter (1949) leaned on the role of economic forces in technical advancement, and underscored that innovation is a necessary driver of economic growth. This economic growth is mainly 
achieved as a result of changes made to the existing market structure through the creation of new goods and services [17]. Similarly, innovation has been defined as a process that creates added value and novelty to the business, its suppliers and customers through the development of new procedures, solutions, products and services as well as new methods of commercialization [34]. Furthermore, it can be perceived as the generation, acceptance and application of ideas which may be novel or a modification of existing processes, products or services [5]. In the light of the foregoing, innovation can be viewed as an organizational action associated with the development of new ideas to enhance the functionality of its existing products or services amid competition or an introduction of something novel in relation to its line of products and services. This view is corroborated by scholars [12] who observed that innovation is associated with the organizations' willingness to depart from existing technologies or practices and venture beyond the current state of market demand.

\subsubsection{Growth}

The concept of growth has over the years been identified as one of the primary indicators of sustainable business performance, and its ultimate survivability. For instance, early scholars on organizational growth and survival have argued that a fast-growing organization that receives a favorable market response and accumulates a resource base is more likely to survive $[27 ; 31]$. It is thus argued that the quest for organizational growth has continued to be a desirable and necessary objective for any organization [45]. But, according to researchers [29], organizational growth means different things to different organizations because there are different indicators organizations use to measure growth. For many organization, the ultimate goal is profitability, and so these organizations measure their growth in terms of net profit and revenue [39]. So, an organization grows if it grows in economic performance and economic results. Also, it has been asserted that growth is a reflection of firms' volume of sales, number of employees, physical expansion, success of a product line, or increased market share [30].

Organizational growth is therefore any observable increase in firms' number of production line, staff strength, profitability and other assets. Noting the essentiality of growth as a measure of survivability, it has been argued that the survivability of any organization is to a large extent a manifestation of its growth rate; and, it is an indication that the organization is doing pretty good in the face of intense competition [14]. It has also been argued that to be successful and remain in business, both profitability and growth are important and perquisites indicators for an organization's survival and continuous attractiveness to investors and analysts [32].

\subsection{Leaders' Normative Isomorphic Pressure and Survivability}

Normative pressures refer to the effect of professional codes of conduct, and the influence of professional communities on organizational characteristics [36]. These standards or codes are usually conveyed through the education and training of professionals and certification processes accredited by professional bodies. As the standard bearers of organizations, leaders feel and act on these pressures before anyone else in the organization. As a form of regulatory pressure, obedience to professional codes of practice projects the image of an organization in a positive light, thus, giving credence to their legitimate existence in the eyes of the society. This is because, these professional bodies determine what is an acceptable behavior [46], and what is unacceptable [22]. The implication of this on survivability is that if the society sees the actions of the organization as being in line with the defined patterns of the profession governing the operations of the organization, they feel safe transacting with such organization. The absence of fear in the minds of the public enhances organizational survivability through continuous patronage. This is buttressed in the argument that normative pressures ensure organizations conform to rules in order to be perceived as partaking in legitimate actions, which also ensure their survivability in the long run [44]. This explains the position that where rules and ethics of professional conduct exist in an organization, motivations for new organizations to pattern themselves as the older organization exist too [36].

Some empirical works have highlighted the predictive effect of normative isomorphic pressures on organizational outcomes including survivability. For instance, it has been found that normative pressures are significant drivers of sustainability reporting in Malaysia [3]. This finding reinforces the statement that the external auditor is responsible for gathering reasonable assurance that the financial statements are free from material misstatement, whether caused by fraud or error [38]. It was thus argued that based on institutional isomorphism, one can expect organizations to impact the activities of their members [9]. This is because the standards or codes of conduct set up by professional organizations are usually adopted by the society as yardsticks for organizational legitimation.

According to some finding on institutional isomorphic pressures and heterogeneity across the healthcare supply chain [7], it showed that a higher level of normative pressures fois manufacturing firms in the health sector were highly associated with improved internal administrative and management practices. In the same manner, it has been discovered [6] that adherence to normative pressures, such as professional norms and ethics compel organizations to be more environmentally sensitive, and argued that institutional study on isomorphism are continuously needed to understand new social rules (e.g. ethical values and ecological thinking), and organizational responses to environmental matters. More so, the study on institutional-based antecedents and performance outcomes of internal and external green supply chain management practices [53] discovered a positive association of normative pressures on internal green supply chain management practices, but no impact was recorded on its external perspective. Conversely, in the study on sustainable supplier development practices in relation to its drivers and enablers [43] the authors found no impact of normative pressures on individual practices such as green 
supplier coordination.

In view of the forgoing empirical outcomes, the following hypotheses were formulated for this study:

$\mathrm{H}_{1}$ : There is no significant interlace between Leaders' normative isomorphic pressure response and innovation of telecommunication firms in Nigeria.

$\mathrm{HO}_{2}$ : There is no significant interlace between Leaders' normative isomorphic pressure response and growth of telecommunication firms in Nigeria.

\section{Methodology}

The blueprint for undertaking this study is explained in the study design adopted. It has been opined [1] that a good research design should capture the type of research the researcher is undertaking, the unit of analysis, as well as the time frame for the study. The research design adopted for this study was cross-sectional survey design which is a form of quasi-experimental approach, with the study unit at the individual level of analysis. The population of this study was drawn from four (4) telecommunication firms in Nigeria with 198 participants drawn from the firms. Given the manageable size of the population, the study adopted census sampling approach. The study data were obtained using structured self-administered questionnaire. Also, a five (5) point Likert scale was used to gauge the participants 'choices and opinions, ranging from strongly agree to strongly disagree. The face validity of the instrument was ascertained through expert review while the Cronbach Alpha coefficients were calculated to ascertain the reliability of the instrument. Based on the results in Table 1, the items were considered reliable.

Table 1. Cronbach's alpha of Study Variables.

\begin{tabular}{lll}
\hline No. of items & Variables & Alpha $(\boldsymbol{\alpha})$ \\
\hline 5 & Normative Pressure of Institutional Isomorphism & 0.837 \\
8 & Survivability & 0.806 \\
\hline
\end{tabular}

Source: Research Data, 2021

In relation to data analysis, the Pearson Product Moment Correlation was utilized to provide answers to the stated research questions and test the hypotheses stated at 0.05 level of significance. Analysis was aided by the use of the Statistical Package for Social Sciences (SPSS version 20).

\section{Data Analyses}

\subsection{Test of Hypothesis One}

$\mathrm{Ho}_{1}$ : There is no significant interlace between Leaders' normative isomorphic pressure response and innovation of telecommunication firms in Nigeria.

Table 2. Correlation between Leaders' Normative Isomorphic Pressure and Innovation.

\begin{tabular}{llll}
\hline & & Leaders' Normative Isomorphic Pressure Response & Innovation \\
\hline & \multirow{2}{*}{ Leaders' Normative Isomorphic } & Correlation Coefficient & 1.000 \\
& Pressure Response & Sig. (2-tailed) &. \\
Pearson & & $\mathrm{N}$ & 189 \\
Correlation & & Correlation Coefficient & $.623^{* *}$ \\
& Innovation & Sig. (2-tailed) & .000 \\
& & $\mathrm{~N}$ & 189 \\
\hline
\end{tabular}

**. Correlation is significant at the 0.01 level (2-tailed).

Source: SPSS Output, 2021.

From the results in table 2, the rho value of 0.623 indicates that there is a strong interlace between leaders' normative pressure response and innovation of telecommunication firms in Nigeria. This interlace is significant at $p=0.000<0.05$ significance level. Thus, the null hypothesis earlier stated is hereby rejected and the alternate accepted to the extent that there exists a significant level of interlaces between leaders' normative pressure response and innovation of telecommunication firms in Nigeria. The study thus found that as leaders respond favourably towards the requirements of professional ethos by aligning their organizations' practices to professional requirements, their organizations will deliver novel outcomes on a continuous basis.

\subsection{Test of Hypothesis Two}

$\mathrm{Ho}_{2}$ : There is no significant interlace between leaders' normative isomorphic pressure response and growth of telecommunication firms in Nigeria.

Table 3. Correlation between Leaders' Normative Isomorphic Pressure and Growth.

\begin{tabular}{llll}
\hline & & & Leaders' Normative Isomorphic Pressure Response \\
\hline & \multirow{2}{*}{ Leaders' Normative Isomorphic } & Correlation Coefficient & 1.000 \\
& Pressure Response & Sig. (2-tailed) &. \\
Pearson & & $\mathrm{N}$ & 189 \\
Correlation & & Correlation Coefficient & $.703^{* *}$ \\
& Growth & Sig. (2-tailed) & .000 \\
& & $\mathrm{~N}$ & 189 \\
\hline
\end{tabular}

**. Correlation is significant at the 0.01 level (2-tailed).

Source: SPSS Output, 2021. 
From the results in Table 3 the rho value of 0.703 reflects a very strong interlace between leaders' normative isomorphic pressure response and growth of telecommunication firms in Nigeria. This observed interlace is considered to be significant at $\mathrm{p}=.000<0.05$ significance level. Thus, the earlier stated null hypothesis is rejected and the alternate accepted. The study thus found that as leaders respond favourably towards the requirements of professional ethos by aligning their organizations' practices to professional requirements, their organizations will experience increased outcomes on a continuous basis.

\section{Discussion of Findings}

Unlike regulatory pressure that is concerned with government and regulatory requirements, normative pressures are borne out of professional associations' standards passed on to members through association. But irrespective of this dichotomy, their concurrent adherence greatly magnifies firms' social legitimacy status and survivability. However, the study findings affirmed that leaders' positive response to normative isomorphic pressures to professionalize their organizations' operation has a positive and significant relationship with Nigeria telecommunication firms' survivability in terms of innovation and growth. The findings indicate that when firms' operational patterns are influenced to conforms to professionalization standards, organizational legitimacy is enhanced while survivability is achieved through goodwill. This is because the operational impact of isomorphic normative pressures on organizations through their leaders provide benefits to the firm. It has been noted that informal social forces such as normative pressures influence those firms concerned with maintaining their legitimacy among other industry members and external stakeholders, in order to achieve survivability [33]. It has been argued [13] that firms' behavior and activities are largely influenced by their quest for social justification, which in the long run fosters their survivability.

In the same manner, firms also respond to normative pressures when they engage the services of similar pool of professionals like consultants [51]. Incidentally, this practice is a dominant one among telecommunication firms in Nigeria; thus, giving credence to their collective acknowledgement of its imperative for their organizations' survivability in this study. The findings also confirm the findings from another work [44] that normative pressures make firms conform to rules in order to be seen as partaking in legitimate activity, which then boost their survivability. Similarly, the findings align with that of other scholars [7] who examined institutional pressures and heterogeneity across the healthcare supply chain and found that significant level of normative pressures for manufacturing firms in the health sector were highly associated with improved internal administrative and management practices, which are necessary ingredient for firms' performance and survivability. This also reinforces the outcome of the study [52] that found that external auditors play vital role in discovering and reporting of corporate fraud. They are able to do this because auditors are professionals whose actions and inactions are guided by normative pressures, which are built on the foundation of high sense of integrity, objectivity and competence. In fact, these values empower them to advise firms' management to be transparent in all their dealings in order to achieve survivability. In the light of these, we state that:

1. Through effective response of leaders to normative isomorphic pressures, telecommunication firms in Nigeria become more innovation driven as a result of their application of various emergent professional codes of conduct developed to enhance business survivability.

2. Through effective response of leaders to normative isomorphic pressures, telecommunication firms in Nigeria experience growth in different areas as a result of increased competitive advantage gained for being ethical.

\section{Conclusion and Recommendations}

Leaning on the findings, the study concludes that through the right response of leaders to normative isomorphic pressures, telecommunication firms in Nigeria as affirmed by through interaction with various professional bodies within the confines of their operational requirements, become progressively aware of global best practices in the world of business which in the long run validates their social legitimacy standing to drive their survivability goal attainment. Thus, the study recommends that the leaders of telecommunication firms in Nigeria should consistently apply their respective professional ethical codes in the discharge of their daily work roles in the organization, as the application of such professional ethics impact positively on the firms' general wellbeing, especially in terms of excellent quality service delivery across the firm's operations in the long run.

\section{References}

[1] Ahiauzu, A. I. (2006). The relevant basic elements of the theory and philosophy of knowledge: An unpublished Lecture Note for PhD Students in Rivers State University of Science and Technology, Port Harcourt.

[2] Akindele, R. I., Oginni, B. O., \& Omoyele, S. O. (2012). Survival of private universities in Nigeria: Issues, challenges and prospects. International Journal of Management, 2 (1), 2 10 .

[3] Amran, A., \& Haniffa, R. (2011). Evidence in development of sustainability reporting: A case of developing country. Business Strategy and the Environment, 20, 141-156.

[4] Ashworth, R., Boyne, G. A., \& Delbridge, R. (2007). Escape from the iron cage? Organizational change and isomorphic pressures in the public sector. Journal of Public Administration Research and Theory, 19 (1), 165-187. 
[5] Babalola, S. S. (2006). Managing innovation, product development and entrepreneurship. In S. Balogun, B. Ehigie, \& A. Sunmola (Eds.), Managerial Psychology: An overview. Ibadan: University of Ibadan, Department of Psychology Publication. 352-387.

[6] Ball, A., \& Craig, R. (2010). Using neo-institutionalism to advance social and environmental accounting: Critical perspective. Account, 21 (4), 283-293.

[7] Bhakoo, V., \& Choi, T. (2013). The iron cage exposed: Institutional pressures and heterogeneity across the healthcare supply chain. Journal of Operation Management, 31 (1), 432 449 .

[8] Biloslavo, R., \& Lynn, M. (2007). Mission statements in Slovene enterprises. Management Decision, 45, 773-788.

[9] Blair, R., \& Janousek, C. L. (2014). City management in the United States and Norway: A comparative analysis of professional orientations. International Journal of Public Administration, 37, 484-493.

[10] Buddelmeyer, H., Jensen, P., \& Wesbster, E. (2010). Innovation and the determinants of company survival. Oxford Economic Papers, 62 (1), 261-285.

[11] Caravella, S. (2015). Defining and assessing professionalism at work. International Journal of Business Management, 287 (2), 226-235.

[12] Covin, J. G., Green, K. M., \& Slevin, D. P. (2006). Strategic process effects on the entrepreneurial orientation-sales growth rate relationship. Entrepreneurship Theory Practice, 30 (1), $57-81$.

[13] Dacin, M., Oliver, C., Roy, J. (2007). The legitimacy of strategic alliances: An institutional perspective. Strategy Management Journal, 28, 169-187.

[14] Darna, N., Sule, E. T., Kusman, M., \& Yunizar, U. (2016). The effect of organizational environment on knowledge management and organizational culture and the implications on organizational survival: A survey based on leaders' perception at private higher education in West Java province. The 8th International Conference on Sustainable Collaboration in Business, Technology, Information and Innovation.

[15] Decramer, A., Smolders, C., Vanderstraeten, A., \& Christiaens, J. (2012). The impact of institutional pressures on employee performance management systems in higher education in the Low Countries. British Journal of Management, 23 (2), 88-103.

[16] Drucker, P., \& Maciariello, J. A. (2008). Management Review. New York: Harper Collins Publishers.

[17] Erengwa, K. N., Nwuche, C. A., \& Anyanwu, S. C. (2017). Employee participation and organizational survival in selected manufacturing firms in Port Harcourt, Nigeria. International Journal of Advanced Academic Research Social \& Management Sciences, 3 (3), 1-10.

[18] Futter, R. (2011). Telecoms infrastructure spend: What are the risks and opportunities to telecoms investment in Africa? BMI-Tech Knowledge Communications Handbook, 26-32.

[19] Gabriel, J. M. O., \& Aborlo, K. G. (2015). Entrepreneurial orientation and survivability of banks in Nigeria: The mediating role of human capital management. The European Business and Management Conference 2015 Official

\section{Conference Proceedings.}

[20] George, B., \& Desmidt, S. (2014). A state of research on strategic management in the public sector: An analysis of the empirical evidence. In P. Joyce \& A. Drumaux (Eds.), Strategic Management in Public Organizations: European Practices and Perspectives (Routledge Critical Studies in Public Management) (151-172). New York: Routledge.

[21] George, B., Baekgaard, M., Decramer, A., Audenaert, M., \& Goeminne, S. (2018). Institutional isomorphism, negativity bias and performance information use by politicians: A survey experiment. Wiley Public Administration, 1-15.

[22] Glover, L. J., Champion, D., Daniels, K. J., \& Dainty, A. J. D. (2014). An institutional theory perspective on sustainable practices across the dairy supply chain. International Journal of Production Economics, 52 (1), 102-111.

[23] Grabher, G. (1993). Rediscovering the social in the economics of inter-firm relations, In Grabher, G, (ed.), The Embedded Firm: On the socio-economics of industrial Networks. London: Routledge.

[24] Granovetter, M. (1985). Economic action and social structure: The problem of embeddedness. American Journal of Sociology, 91 (1), 481-493.

[25] Huggins, R. (2000). The Business of Networks. Inter-firm Interaction, Institutional Policy and the TEC Experiment. Aldershot UK: Ashgate.

[26] Jaja, S. A., Gabriel, J. M. O., \& Wobodo, C. C. (2019). Organizational isomorphism: The quest for survival. Noble International Journal of Business and Management Research, $3(5), 86-94$.

[27] Jovanovic, B. (1982). Selection and the evolution of industry. Econometrica, 50, 649-670.

[28] Katopol, P. (2016). Isomorphism and barriers to organizational change. Library Leadership \& Management, 30 (2), $1-5$

[29] Laosebikan, J. S., Oginni, B. O., \& Ogunlusi, C. F. (2013). Evaluation of time management for growth and development in developing economies: Nigerian experience. International Journal of Innovative Research and Development, 2 (7), 490496.

[30] Lipton, M. (2003). Guiding Growth: How vision keeps companies on course. Harvard: Harvard Business School Publishing Corporation.

[31] Mata, J., Portugal, P., \& Guimarães, P. (1995). The survival of new plants: Start-up conditions and post-entry evolution, International Journal of Industrial Organization, 13 (1), 459481.

[32] Maverick, J. B. (2020). Is profitability or growth more important for a business? Accessed from https://www.investopedia.com/ask/answers/020415/whatmore-important-business-profitability-or-growth.asp3/3/2020.

[33] May, P. J. 2004. Compliance motivations: Affirmative and negative bases. Law Social. Review, 3 (8), 41-68.

[34] McFadzean, E., O’Loughlin, A., \& Shaw, E. (2005). Corporate entrepreneurship and innovation part 1: The missing link. European Journal of Innovation Management, 8 (3), 350-372. 
[35] Mizruchi, M., \& Fein, L. C. (1999). The social construction of organizational knowledge: A study of the uses of coercive, mimetic, and normative isomorphism. Administrative Science Quarterly, 44 (4), 653-74.

[36] Munene, J. C. (2009). The Management of Universal Primary Education in Uganda. Nairobi: Organisation for Social Science Research in Eastern and Southern Africa.

[37] Nwosu, H. E. (2014). Succession planning and corporate survival: A study of selected Nigeria Firms. International Journal of Business \& Management, 2 (3), 6-19.

[38] Nyahas, S. I., Munene, J. C., Orobia, L. \& Kaawaase, T. K. (2017). Isomorphic influences and voluntary disclosure: The mediating role of organizational culture. Cogent Business \&Management, 4 (4), 135-1144.

[39] Oginni, B. O., \& Adesanya, A. S. (2013). Business environmental factors: Implications on the survival and growth of business organizations in the manufacturing sector of Lagos metropolis. Business and Management Research, 2 (3), 146-155.

[40] Oyeniran, W. I. \& Onikosi-Alliyu, S. (2016). Information and telecommunication infrastructure and economic growth: An experience from Nigeria. Serbian Journal of Management, 11 (2), 275-289.

[41] Popadiuk, S., Rivera, E. R. \& Bataglia, W. (2014). Heterogeneity of isomorphic pressures: Intertwining the resource-based view and the neo-institutional approach. Brazilian Administrative Review, 11 (4), 455-75.

[42] Recker, G. (2002). Organizational survival within a declining industry: An analysis of a single sex boarding school. The International Journal of Educational Management, 16 (2), 2029.

[43] Sancha, C., Longoni, A., \& Giménez, C. (2015). Sustainable supplier development practices: Drivers and enablers in a global context. Journal of Purchasing and Supply Management, 21 (3), 95-102.

[44] Sarkis, J., Zhu, Q., \& Lai, K. H. (2011). An organizational theoretic review of green supply chain management literature. International. Journal of Production Economics, 1 (130), 115.

[45] Satyendra (2019). The organization grows if it grows in economic performance and economic results. Journal of Management, 4 (1), 62-74.

[46] Scott, R. W. (2014). Institutions and Organizations Ideas, Interests and Identities. London: Sage Publications.

[47] Seyfried, M., Ansmann, M., \& Pohlenz, P. (2019). Institutional isomorphism, entrepreneurship and effectiveness: The adoption and implementation of quality management in teaching and learning in Germany. Tertiary Education and Management, 25 (2), 115-129.

[48] Ugwuzor, M. (2017). Survivor behaviour management and organizational survival. International Journal of Commerce, Business and Management, 28 (6), 12-80.

[49] Uzzi, B. (2000). The sources and consequences of embeddedness for the economic performance of organizations: The network effect. American Sociological Review, Ms. 1 (3), 94-289.

[50] Vanalle, R. M., Ganga, G. M. D., Filho, M. G., \& Lucato, W. C. (2017). Green supply chain management: An investigation of pressures, practices, and performance within the Brazilian automotive supply chain. Journal of Cleaner Production 15 (1), 250-259.

[51] Washington, M. \& Patterson, K. D. (2011). Hostile takeover or joint venture: Connections between institutional theory and sport management research. Sport Management Review, 14 (1), $1-12$.

[52] Zhou, Y. (2012). The role of external auditors in detecting and reporting corporate fraud in public listed companies in China. International Journal of Business Administration, 3 (1), 2-15.

[53] Zhu, Q., Sarkis, J., \& Lai, K. (2013). Institutional-based antecedents and performance outcomes of internal and external green supply chain management practices. Journal of Purchasing and Supply Management, 19 (1), 106-117. 